\title{
The influence of creatine use on performance of swimmers
}

\author{
Hakan ACAR ${ }^{1}$, Erkut TUTKUN², Osman İMAMOĞLU³ ${ }^{3}$ Tülin ATAN ${ }^{3}$
}

\author{
${ }^{1}$ Zonguldak Bülent Ecevit University, School of Physical Education and Sport, Zonguldak, Turkey \\ ${ }^{2}$ Uludăg University, Faculty of Sport Sciences, Bursa, Turkey, \\ ${ }^{3}$ Ondokuz Mayıs University Yaşar Doğu Faculty of Sport Sciences, Samsun, Turkey \\ Address correspondence to E.Tutkun,erkuttutkun@gmail.com
}

\begin{abstract}
The aim of this study is to examine the effects of creatine use on the performance of swimmers. The existing literature was reviewed. The studies were presented in tables. It was found that most of the studies on creatine use in swimming branch were on single sprint performance, repeated interval swimming set performance and increase in strength. Increases were found in maximal swimming time and recovery capacity. 1,52\% performance increase was found in sprint swims. Increases between $2-8 \%$ were found in total work performance. There were also studies which did not report any effect of creatine on performance. One of the reasons why such studies did not report any effects is insufficient creatine loading. In swimmers who use creatine, the effects are generally seen in fat-free body weight, total body weight and amount of body water. In controlled studies conducted on swimmers, both plasma concentration increase and elevation of total creatine amount in muscles can occur with creatine supplement intake (daily about $20 \mathrm{gr}$ ). This increase can be positively reflected in performance. It can contribute to swimmers' aerobic and anaerobic endurance of upper and lower extremities, sprint running and sprint swim speed, maximal strength and strength continuity and recovery speed in-between repeats and post-training. Its use should be conducted in normal doses under physician control.
\end{abstract}

Keywords: Swimming, Creatine, Performance

\section{INTRODUCTION}

Today, Swimming is a situation in which the swimmers must float in a liquid like water to compete. The more velocity of the swimmers raises the more resistance of water as much as second power regardingly. Hence, swimmers need to some factors such as strength and power of muscles and improvement of performances to meet these high demands. athletes have continuously sought elixirs to enhance their performance. Creatine is one of the most commonly used dietary supplements (2). Supplementation with creatine increases an individual's total muscle creatine content (i.e. intramuscular phosphocreatine and creatine (33). A relatively large scientific body of literature has been generated over the past decade documenting the physiologic and performance effects of creatine supplementation in diverse populations (31). It is a commonly held view that creatine use supports sportive performance with a wide popularity among athletes (24).

Creatine is an amino acid synthesized primarily in the liver and stored mostly in the muscle (32).
Creatine plays a very important role in skeletal muscle, heart, brain, cells for seeing in the eyes and sperms. In high and increasing energy metabolism, creatine and creatine phosphate are physiologically very important metabolites for cells to generate cellular energy. When $20 \mathrm{mg}$ creatine is taken daily, 10 times more creatine is synthesized in the body. The body can store an additional $100 \mathrm{mg}$ creatine. Human organism needs daily 2 gr creatine and it is mostly synthesized in the liver $(9,26)$. Since its daily synthesis is not enough in the body, half of it should be taken from the outside. Half of 3-5 grams can be taken from animal protein such as meat and fish. 1 gr of creatine is isolated with 23 gr of water. Its side effect which occurs as weight increase is between $1,8-2 \mathrm{~kg}$ depending on the period and amount of use $(6,16)$. Few official toxicity studies have been conducted to assess the potential side effects of creatine supplement (3). In addition to benefits of creatine use, its possible side effects can be listed as muscle cramps, nausea, diarrhea, dizziness, gastrointestinal pain, dehydration, weight gain, 
hydration, heat intoleration and fever (34). There is no well-prepared report on the side-effects of creatine supplements. It is hoped that creatine loading does not have short and long-term harmful effects on health. The only change that is found more or less continuous is the increase in fat-free body weight (21).

A great number of studies show that creatine supplement actively increases neuromuscular performance in anaerobic and intermittent exercises and that it is very useful for high power that athletes require (10). English sprinters and disabled runners who used creatine in 1992 Olympics were successful. The success of Olympics champion Linford Christie was considered to be due to creatine intake. $3 / 4$ (three out of four) swimmers who won medal in 1996 Atlanta Summer Olympics had a good reason to use creatine: because trainers and athletes believed that it worked and it was even found to work. It is estimated that more than $80 \%$ of the athletes who participated in Atlanta Olympics used creatine. Gold medals were won in national and international competitions with creatine as natural performance improver (11).

While it was found creatine have positive effects in some studies and on some individuals, in some studies it was found that creatine have no positive effects. This means that supplement creatine intake does not cause an effect on all individuals and it can caused side-effects.

In swimming, it was not found to have positive effects on $6 \%$ of all individuals. Mostly female athletes in strength, quick strength and endurance sports believe in its effect. The aim of this study was to investigate the influence of creatine use on performance of swimmers.

\section{INTERPRETATION OF ANALYSIS \& FINDINGS}

Results of some studies conducted in the branch of swimming are presented in the tables below.

In the table- 1 studies about the effect of creatine supplement on single sprint in swimming is presented.

Table 1. The effect of creatine supplement on single sprint in swimming

\begin{tabular}{|c|c|c|c|c|}
\hline Study & Year & Dosage+Protocol & Group & Findings \\
\hline $\begin{array}{c}\text { Anomas } \\
\text { iri (1) }\end{array}$ & 2004 & $\begin{array}{l}\text { While the creatine group received } 10 \\
\text { gr creatine monohydrate and } 30 \mathrm{gr} \\
\text { orange juice every day for } 7 \text { days, } \\
\text { control group received only } 30 \mathrm{gr} \\
\text { orange juice. }\end{array}$ & $\begin{array}{l}38 \text { male swimmers ( } 19 \\
\text { in the creatine group, } \\
19 \text { in the control } \\
\text { group). }\end{array}$ & $\begin{array}{l}\text { In amateur swimmers, body weight and fat- } \\
\text { free weight increased with daily } 10 \mathrm{gr} \\
\text { creatine for } 7 \text { days. In addition, sprint time } \\
\text { in the last } 50 \text { meters of } 400 \text { meters decreased } \\
\text { significantly. }\end{array}$ \\
\hline $\begin{array}{c}\text { Burke et } \\
\text { al. (4) }\end{array}$ & 1996 & $\begin{array}{l}5 \text { gr creatine monohydrate }-2 \text { gr } \\
\text { sucrose (a total of } 20 \text { gr a day), } 4 \\
\text { times a day and for } 5 \text { days. } 1 \times 25 \mathrm{~m} \\
\text { sprint, } 1 \times 50 \text { m sprint and } 1 \times 100 \mathrm{~m} \\
\text { sprint. } 10 \text { minutes of active recovery, } \\
2-3 \text { minutes of passive recovery in- } \\
\text { between sprints. }\end{array}$ & $\begin{array}{l}32 \text { elite female (14) } \\
\text { and male (18) } \\
\text { swimmers in national } \\
\text { level. }\end{array}$ & $\begin{array}{l}\text { No significant performance changes was } \\
\text { found in any of the trials. No effect on body } \\
\text { composition. }\end{array}$ \\
\hline $\begin{array}{l}\text { Peyrebr } \\
\text { une et } \\
\text { al.,(7) }\end{array}$ & 2000 & $\begin{array}{l}\text { Daily } 2 \times 10 \text { gr creatine ( } 20 \mathrm{gr} \\
\text { creatine) monohydrate Trainings } \\
\text { were in the form of normal } \\
\text { swimming training for } 16 \text { weeks. }\end{array}$ & $\begin{array}{l}\text { Male swimmers in a } \\
\text { university team } \\
\text { (randomly } 12 \\
\text { individuals) }\end{array}$ & $\begin{array}{l}\text { Who received creatine, swimming } \\
\text { performance time was significantly better in } \\
\text { mixed } 25 \mathrm{~m} \text { when compared with the group } \\
\text { who did not. While } 25 \text { meter sprint } \\
\text { swimming performance was first } 6,2 \mathrm{sec} \\
\text { and later } 6,0 \text { sec in the group which did not } \\
\text { receive creatine, it was first } 6,3 \mathrm{sec} \text { and later } \\
5,6 \text { sec in the group which received creatine } \\
\text { and this decrease was found to be } \\
\text { statistically significant. }\end{array}$ \\
\hline $\begin{array}{l}\text { Dawson } \\
\text { et al. (8) }\end{array}$ & 2002 & $\begin{array}{l}\text { Daily } 20 \text { gr creatine monohydrate } \\
\text { loading for } 5 \text { days, during the } \\
\text { maintenance period, daily } 5 \text { gr } \\
\text { creatine monohydrate was loaded } \\
\text { for } 22 \text { days .( } 5 \text { gr creatine } \\
\text { monohydrate- } 1 \text { gr glucose polymer } \\
\text { and } 6 \text { gr glucose polymer). Before } \\
\text { loading, } 50 \text { meter free style with } 5 \\
\text { minutes of active recovery and } 100 \\
\text { m maximum speed free style sprint } \\
\text { swimming. } 3 x 100 \text { m recovery } \\
\text { swimming over } 1,5 \text { minutes of } \\
\text { interval. Height, weight, skin fold }\end{array}$ & $\begin{array}{l}\text { Randomized, single- } \\
\text { blind. } 10 \text { male and } 10 \\
\text { female competitive } \\
\text { young swimmers ( } 16 \\
\text { years of age), (10 } \\
\text { samples creatine, } 10 \\
\text { placebo). }\end{array}$ & $\begin{array}{l}\text { Creatine loading did not affect body mass } \\
\text { or composition or individual performance } \\
\text { in the pool. No positive changes were found } \\
\text { in sprints. After creatine intake, } 30 \text { sec. } \\
\text { swimming bench total work score increased } \\
\text { in the first and second trial ( } \mathrm{p}<0.05 \text { ), but not } \\
\text { in placebo. Post-exercise blood lactate levels } \\
\text { were not different in } 50 \text { and } 100 \text { meter } \\
\text { sprints after loading within the groups or } \\
\text { between the groups. While creatine intake } \\
\text { did not significantly improve individual } \\
\text { performance of competitive young } \\
\text { swimmers, it increased performance in }\end{array}$ \\
\hline
\end{tabular}


thickness from 6 areas, Biokinetic swimming bench total productivity test $(2 \times 30 \mathrm{sec}$. with $10 \mathrm{~min}$. of passive recovery in-between)

\begin{tabular}{|c|c|c|c|c|}
\hline $\begin{array}{c}\text { Havene } \\
\text { tidis et } \\
\text { al.(13) }\end{array}$ & 1996 & $\begin{array}{l}2 \text { different supplement period: } 5 \text { gr } \\
\text { creatine and } 5 \text { gr placebo with } 4 \\
\text { months in-between, } 5 \text { times a day, } \\
\text { for } 4 \text { days. Non-randomized, } \\
\text { double-blind. Distance not specified. }\end{array}$ & $\begin{array}{l}21 \text { elite swimmers (11 } \\
\text { males, } 10 \text { females). }\end{array}$ & $\begin{array}{l}\text { Significant improvement in competition } \\
\text { time }(2,1 \%) \text { following the first } \\
\text { supplementation period, in creatine group. } \\
\text { More improvement in the competition time } \\
\text { following the second period, for the creatine } \\
\text { group }(3,0 \%) \text {. }\end{array}$ \\
\hline $\begin{array}{c}\text { Mendes } \\
\text { et } \\
\text { al.(19) }\end{array}$ & 2004 & $\begin{array}{l}\text { Double blind, placebo controlled. } 5 \\
\text { gr creatine }+20 \text { gr carbohydrate and } \\
\text { Placebo } 20 \text { gr carbohydrate. } 4 x \text { every } \\
\text { day, } 8 \text { days, } 1 \times 50 \mathrm{~m} \text { sprint and } 1 x \\
100 \mathrm{~m} \text { sprint }\end{array}$ & $\begin{array}{c}18 \text { competition } \\
\text { swimmers (12 males, } 6 \\
\text { females, average age } \\
19) .\end{array}$ & $\begin{array}{l}\text { It was not influential on the performance of } \\
\text { each group. Only in the creatine group, fat- } \\
\text { free body weight, total bodyweight and } \\
\text { body water amount were found to increase } \\
\text { significantly. No change was found in } \\
\text { muscle mass. }\end{array}$ \\
\hline $\begin{array}{c}\text { Mujika } \\
\text { et } \\
\text { al.(22) }\end{array}$ & 1996 & $\begin{array}{l}5 \text { gr creatine monohydrate and } 5 \text { gr } \\
\text { lactose (placebo)four times a day } \\
\text { during } 5 \text {-day long exercises (a total } \\
\text { of daily } 20 \text { gr). } 1 \times 25 \mathrm{~m}, 1 \times 50 \mathrm{~m} \text { and } \\
1 \times 100 \mathrm{~m} \text { sprint consisting of } 300 \mathrm{~m} \\
\text { active recovery, 20-25 min passive } \\
\text { recovery in-between sprints. }\end{array}$ & $\begin{array}{l}\text { Randomly chosen } 11 \\
\text { male and } 9 \text { female } \\
\text { national or } \\
\text { international } \\
\text { swimmers }\end{array}$ & $\begin{array}{l}\text { Body weights of the group which received } \\
\text { creatine increased significantly with a rate } \\
\text { of } 1 \%(0,7 \mathrm{~kg}) \text {. No differences were found } \\
\text { between the observed groups in terms of } \\
\text { performance creatine. A significant } \\
\text { decrease was found in pre-exercise } 50 \text { and } \\
100 \mathrm{~m} \text { distances in the creatine group. }\end{array}$ \\
\hline $\begin{array}{l}\text { Peyrebr } \\
\text { une et } \\
\text { al. (23) }\end{array}$ & 1998 & $\begin{array}{l}\text { Randomized double blind. Daily } 9 \mathrm{~g} \\
\text { creatine+4,5 gr maltodextrin }+4,5 \mathrm{gr} \\
\text { glucose for } 5 \text { days. Placebo group } \\
\text { received } 18 \mathrm{gr} \text { glucose daily. } 1 \times 50 \\
\text { yard }(45.72 \mathrm{~m}) \text { single sprint }\end{array}$ & $\begin{array}{l}14 \text { national elite male } \\
\text { swimmers and } \\
\text { placebo (20-21 years of } \\
\text { age). }\end{array}$ & $\begin{array}{l}\text { Creatine was not found to influence single } \\
50 \text { yard sprint performance. }\end{array}$ \\
\hline $\begin{array}{l}\text { Selsby } \\
\text { et } \\
\text { al.(25) }\end{array}$ & 2003 & $\begin{array}{l}5 \text { days of loading: } 0,3 \text { gr creatine per } \\
\text { kilogram and dextrose for placebo. } \\
\text { During maintenance period, creatine } \\
\text { group received daily } 2,25 \mathrm{gr} \\
\text { creatine, while placebo group } \\
\text { received dextrose for } 9 \text { days. Daily } \\
2,25 \text { gr creatine was given for } 9 \text { days } \\
\text { regardless of the body weights of } \\
\text { samples who were loaded with } \\
\text { creatine. }\end{array}$ & $\begin{array}{l}\text { Randomized, double } \\
\text { blind study. } 8 \text { male } \\
\text { and } 7 \text { female college } \\
\text { swimmers. }\end{array}$ & $\begin{array}{l}\text { There was a significant decrease in the } \\
\text { average performance time of the creatine } \\
\text { supplement group in } 50 \text { yard free style. } \\
\text { Creatine load was found to positively } \\
\text { influence } 50 \text { and } 100 \text { yard single effort } \\
\text { sprint degrees of college 3rd league } \\
\text { swimmers. }\end{array}$ \\
\hline $\begin{array}{c}\text { Thomps } \\
\text { on et al. } \\
(30)\end{array}$ & 1996 & $\begin{array}{l}2 \text { gr creatine and } 2 \text { gr placebo for } 42 \\
\text { days during training. Free style: } 1 x \\
100 \text { m sprint and } 1 \times 400 \mathrm{~m} \\
\text { sprint.Rest and exercise ( } 10 \text { and } 15 \\
\text { minutes of submaximal plantar } \\
\text { flexion move). ATP and creatine } \\
\text { phosphate concentrations were } \\
\text { determined by using } 31 \text { p MRS. }\end{array}$ & $\begin{array}{l}\text { Randomized, double } \\
\text { blind placebo } \\
\text { controlled study. } 10 \\
\text { female university } \\
\text { swimmers }\end{array}$ & $\begin{array}{l}\text { For each group, no significant effect of } \\
\text { creatine was found on swimming time with } \\
\text { each sprint. The differences between } \\
\text { groups during exercise, post-exercise and } \\
\text { rest were not significant. No significant } \\
\text { increase was found in fat-free body weight. }\end{array}$ \\
\hline
\end{tabular}

In a few studies it was found significant decreases in the average performance time of the creatine supplement group, but generally results showed that creatine has no significant effect on swimming time in sprints in a variety of different supplementation regimes and a single sprint swim does not improve following creatine supplementation. According to this studies it can be said that it is unlikely creatine supplementation would be of benefit to single sprint performance in swimming. swimming bench test.

Significant improvement in competition me $(2,1 \%)$ following the first group $(3,0 \%)$. free body weight, total bodyweight and body water amount were found to increase was found in of $1 \%(0,7 \mathrm{~kg})$. No differences were found between the observed groups in terms of erformance creatine. A significan $100 \mathrm{~m}$ distances in the creatine group.

Creatine was not found to influence single swimmers and age). blind study. 8 male 7 female college influence 50 and 100 yard single effort sprint degrees of college 3rd league swimmers.
In the table-2 studies about the effect of creatine supplement on repeated interval performance in swimming is presented. decrease was found in pre-exercise 50 and 
Table 2. The effect of creatine supplementation on repeated interval set performance in swimming

\begin{tabular}{|c|c|c|c|}
\hline Study & Year Dosage+Protocol & Group & Findings \\
\hline $\begin{array}{l}\text { Carl et al. } \\
\text { (5) }\end{array}$ & 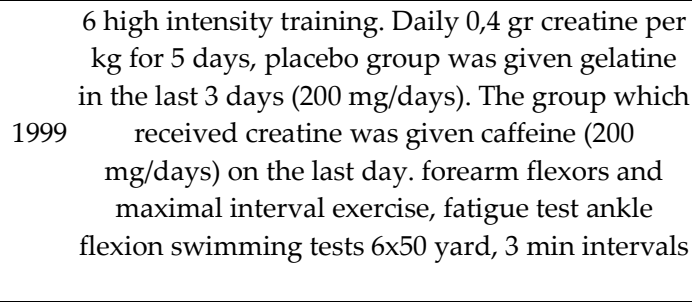 & $\begin{array}{c}\text { Female } \\
\text { swimmers } \\
\text { and placebo } \\
\text { group }\end{array}$ & $\begin{array}{l}\text { Total strength was found to increase significantly in } \\
\text { swimmers who received creatine and caffeine } \\
\text { together, it was not found to increase in swimmers } \\
\text { who received only creatine. When long rests were } \\
\text { given within creatine repeats ( }>3 \text { minutes), } \\
\text { swimming performance was found to be } \\
\text { influenced; however, when rest intervals were short } \\
\text { (<30seconds), no influences were found. }\end{array}$ \\
\hline
\end{tabular}

2 different supplementation periods: 5 gr creatine and 5 gr placebo with 4 months interval, 5 times a

Havenetidi 1996 day for 4 days. Non-randomized, double blind.

s et al.(13) $\quad 10 \times 50 \mathrm{~m}$ sprint with 1 minute intervals, $8 \times 100 \mathrm{~m}$ sprint with 2 minute intervals and $15 \times 100 \mathrm{~m}$ sprint with 40 seconds intervals

21 elite swimmers (11 males, 10 females)
Greater recovery in performance for the creatine group when compared with the placebo group in the first supplementation period. Greater recovery in the performance in second supplementation period for creatine group.
Randomized, double blind placebo controlled.

Daily21 gr. creatine monohydrate and 4,2 gr

Grindstaff 1997 maltodextrin and daily 25 gr maltodextrin for 9 et al.(12)

$$
\text { days during training. }
$$

$3 \times 100 \mathrm{~m}$ competition tempo free style swimming with 60 seconds of passive rest and $3 \times 20 \mathrm{sec}$ upper extremity isokinetic arm ergometry test with $60 \mathrm{sec}$ of rest
18 junior

(11 female and 9 male swimmers)

American regional and national amateur swimmers

In the creatine group, body weight increase was not significant $(0,5 \mathrm{~kg})$. Fat mass and fat ratio were found to decrease. $100 \mathrm{~m}$ swim degree was found be significantly faster in the first training $(1,1 \mathrm{sec})$.

$100 \mathrm{~m}$ swim degree was found to decrease swimming time in the second training, too. Improvements in swimming times in all three trainings. In the upper extremity training, work was significantly more in the creatine group when compared with the placebo group; however, no significant difference was found in the second and third sprints. Total swimming time was found to decrease in the creatine group.

Double blind study Swimming time was not found to decrease.

Jacobs et al. Two-week long creatine intake on 50 meter $(6 \times 50,18$ male and Creatine supplementation was not found to affect (14) 1998 meter twice a week) and 25 yard (10x25 twice a 14 female week) on speed.

college swimmers performance development in female swimmers; however, a development of higher than 30-35 seconds was found in exercise repetition times in male swimmers.

11 German In sprint interval training, $1,52 \%$ performance
swimmers increase and endurance development was reported

(8 male and in sprint swims following high dose creatine intake.

3 female Creatine supplement was not found to have an

swimmers effect on either gender or 10x 25 yard intervals. In about $\quad 6 \times 50$ meter series, while no effect was found in

Leemputte et $1999 \quad 5 \times 5$ gr creatine intake for 4 days.

18 years old females, positive effect was found in males. who Creatine supplementation was not found to affect

had at least 5 performance development in female swimmers; years of however, a development of higher than 30-35 swimming seconds was found in exercise repetition times in training), male swimmers.

\begin{tabular}{|c|c|c|c|c|}
\hline $\begin{array}{l}\text { Leenders } \\
\text { et al. (18) }\end{array}$ & 1996 & $\begin{array}{c}\text { Double blind randomized, } \\
20 \text { gr creatine and placebo for } 14 \text { days during } \\
\text { training. Interval tests: } 6 \text { x50 m swimming (with } \\
180 \text { sec recovery), } \\
\text { 10x25 m swimming (with } 60 \text { sec recovery), } 12 \times 100 \\
\text { m (with } 150 \text { sec recovery) }\end{array}$ & $\begin{array}{l}\text { Male and } \\
\text { female } \\
\text { university } \\
\text { student } \\
\text { swimmers }\end{array}$ & $\begin{array}{l}\text { No difference was found between groups in 10x25 } \\
\text { and } 12 \times 100 \text { meter sprint times. However, } \\
\text { significant decrease was found in } 6 \times 50 \text { meter } \\
\text { swimming time. As a conclusion, significant } \\
\text { resistance was found in creatine group for speed } \\
\text { increase in interval set swims. }\end{array}$ \\
\hline \multirow[t]{2}{*}{$\begin{array}{l}\text { Mendes } \\
\text { and } \\
\text { Tirapegui } \\
\quad(19)\end{array}$} & 2004 & $\begin{array}{l}\text { Double blind, placebo controlled } \\
5 \text { gr creatine }+20 \text { gr carbohydrate and placebo } 20 \\
\text { gr carbohydrate. } 4 \text { x every day, for } 8 \text { days. } 3 \times 3 \times 50 \mathrm{~s} \\
\mathrm{~m} \text { sprint with } 30 \text { sec interval between sprints and } \\
\quad 150 \text { sec interval between sets. }\end{array}$ & $\begin{array}{c}18 \\
\text { competition } \\
\text { swimmers (12 } \\
\text { males, } 6 \\
\text { females, } \\
\text { average age } \\
\text { 19). } \\
\end{array}$ & $\begin{array}{l}\text { It was not found to be effective on the performance } \\
\text { of each group. Only in the creatine group, fat-free } \\
\text { body weight, total body weight and body water } \\
\text { amount were found to increase significantly. No } \\
\text { change was found in muscle mass. }\end{array}$ \\
\hline & & $\begin{array}{l}\text { Supplementation was implemented in two } \\
\text { different times (with } 30 \text { days interval), } 5 \text { gr } \\
\text { creatine and } 5 \text { gr maltodextrin } 4 \text { times a day for } 6\end{array}$ & 6 national & $\begin{array}{l}\text { Greater increase was found in swimming time in } \\
\text { placebo group between } 2 \text { sprints. No significant } \\
\text { change was found in body weight and fat } \\
\text { percentage. While the values were similar in the }\end{array}$ \\
\hline
\end{tabular}


Mero et al. 2004 days. 0,3 gr maltodextrin and 0,3 gr Sodium (20)

bicarbonate for each body weight $\mathrm{kg}$ on the test day (placebo and creatine +sodium bicarbonate). Free style: $2 \times 100 \mathrm{~m}$ sprint with 10 minutes of passive rest between sprints swimmers (8 first one, sodium bicarbonate group was found to males and 8 have 0,9 sec better degree than the sodium females, bicarbonate group in the second one. Simultaneous average age bicarbonate and creatine supplementation between 17 increased performance in consecutive maximal and 18). swims. As a result of the test, increase was found in maximal swimming time and recovery ability.

\begin{tabular}{cc}
\hline $\begin{array}{c}\text { Peyrebrune 1998 } \\
\text { et al. (23) }\end{array}$ & $\begin{array}{c}\text { Randomized double blind } \\
\text { For five days daily } 9 \mathrm{~g} \text { creatin }+4,5 \mathrm{gr} \\
\text { maltodextrin }+4,5 \text { gr glucose, placebo group } \\
\text { received daily } 18 \text { gr glucose. } 8 \times 50 \text { yard }(45.72 \mathrm{~m}) \\
\text { sprint with intervals of } 1 \text { minute-30 seconds. }\end{array}$ \\
\hline $\begin{array}{c}\text { Creatine group }(0,3 \mathrm{gr} / \mathrm{kg}) \text { and low dose creatine } \\
\text { group }(0,07 \mathrm{~g} / \mathrm{kg}) \text { and placebo group were given } 5\end{array}$
\end{tabular}
Selsby et 2001 days of loading and daily 2 gr maintenance in the al. (25) following 9 days. Swimming bench ergometry test in 50 and 100 yrd sprint $4 \times 50$ yard 2 min rest intervals and at $20 \mathrm{sec}$ maximal effort.

$$
\text { Randomized }
$$

Theodorou Acute creatine loading: daily 5 times 5 gr creatine and Cooke 1998 for 4 days, maintenance period: 5 gr creatine and

5 gr Placebo once a day and for 8 weeks. $10 \times 50 \mathrm{~m}$ sprint; 60 sec swimming time recovery. $8 \times 100 \mathrm{~m}$ sprint; 2 min swimming time recovery

\section{4 male}

national swimmers

and placebo

(20-21 years of age),
In the creatine group, significant decrease (2\%) was found in total swim time.
In both groups, significant increase was found in 50 and 100 yrd high dose sprint performance. No differences were found in repeated intervals and 8 male and 13 female elite swimmers swimming bench between groups.

Significant recovery $(2 \%)$ was found in average

12 Elite swimming (8 males, 4 females) average age

17 swimming time following acute creatine loading. No significant difference was found between average swimming time between the end of two months and following acute loading.

\section{Randomized}

Acute creatine loading: daily 5 times 5 gr creatine Theodorou 1999 monohydrate for 4 days, maintenance period: 5 gr 22 national et al.(28)

creatine monohydrate and 5 gr politen glycol swimmers (12 4000 , once a day and for 8 weeks. $10 \times 50 \mathrm{~m}$ sprint; males, 10 $60 \mathrm{sec}$ swimming time recovery, 8x100 m sprint; 2 females), min swimming time recovery, $15 \times 100 \mathrm{~m}$ sprint; 2 average age min swimming time recovery
Randomized

5 gr creatine and 5 gr creatine $+500 \mathrm{ml}$ glucose syrup, 5 times a day for 4 days.

Theodorou 2005 et al.(29) 10x50 m sprint; 60 sec swimming time recovery, $8 \times 100 \mathrm{~m}$ sprint; 2 min swimming time recovery
Swimmers were tested before and after a 27-daylong supplementation. They swam 50 meter free style and after that (after 5 minutes of active rest), 100 meter free style with high speed. Blood

Dawson et 2002 lactate was measured before each swim and 1 al., (8)
10 high performance swimmers $(6$ males and 4 females, average age17-18).
Significant recovery $(1,52 \%)$ was found in average swimming time following acute creatine loading.

No significant difference was found between average swimming time between the end of two months and following acute loading. Significant increase $(0,6 \%)$ was found in body weight following acute creatine loading.

Significant development in swimming speed for both groups ( $2 \%$ for the group which received only creatine and $0,7 \%$ for the group which received creatine +carbohydrate). Swimmers mostly had weight increase. Average weight increase was greater in the creatine +carbohydrate group when compared with only creatine group. A significant and positive association was found between average speed increase and average body weight of creatine and only carbohydrate group.

Following a 4-week-long oral creatine intake, free style sprint swimming and swimming chest press performance was found to increase in young swimmers. Post-exercise blood lactate value was

10 young not different between groups or within groups for males and $10 \quad 50 \mathrm{~m}$ and $100 \mathrm{~m}$ sprint. Following 4-week-long young supplementation, the increase in sprint females performance of young competitor swimmers was not significant; however, an increase was found in swimming bench test performance.

In the table- 3 studies about the effect of creatine

In the studies different results was found on repeated interval set performance in different usages of creatine. Some evidence exists to support a beneficial effect of creatine supplementation on repeated exercise performance. According to some studies it can be said that using creatine alone didnt lead performance improvements. supplementation strength in swimming is presented. 
Table 3. The effect of creatine supplementation on strength increase in swimming

\begin{tabular}{|c|c|c|c|c|}
\hline Study & Year & Dosage+Protocol & Group & Findings \\
\hline Anomasiri (1) & 2004 & $\begin{array}{l}\text { Daily creatine monohydrate and } 30 \mathrm{gr} \\
\text { orange juice for } 7 \text { days in the creatine } \\
\text { group and only } 30 \text { gr orange juice in the } \\
\text { control group. In addition to anaerobic } \\
\text { strength and capacity, fatigue indexes } \\
\text { were tested with } 30 \mathrm{sec} \text {. Wingate arm } \\
\text { ergometry. Sprint times in the last } 50 \\
\text { meters of } 400 \text { meters swimming } \\
\text { competition were taken. }\end{array}$ & $\begin{array}{l}38 \text { male swimmers } \\
\text { between the ages of } \\
16 \text { and } 23 \text { (19 in the } \\
\text { creatine group and } \\
19 \\
\text { in the control } \\
\text { group) }\end{array}$ & $\begin{array}{l}\text { Anaerobic strength of the group which used } \\
\text { creatine was found to increase significantly. }\end{array}$ \\
\hline
\end{tabular}
loading: daily 20 gr creatine and sucrose for placebo. (5 gr creatine monohydrate 2 gr sucrose and 5 gr polyglucose- 2 gr

Burke et al. sucrose) four times a day for 5 days. National and No difference was found between work

(4) 1996 Cycle ergometry: 2x10 sec maximal effort international 18 performance, peak strength or peak strength sprint with $10 \mathrm{~min}$ of rest in-between male and 14 female times of groups or trials. sprints, swims: a)2x10 sec, b)25m./50m. Australian Swimming program: $1 \times 25 \mathrm{~m}$ sprint, $1 \times 50 \quad$ swimmers. m sprint, $1 \times 100 \mathrm{~m}$ sprint 10 minutes of active recovery, 2-3 minutes of passive recovery between sprints

Randomized, (10 in creatine group, 10 in placebo group). Daily 20 gr creatine monohydrate loading for 5 days and daily Dawson et $\quad 5$ gr creatine monohydrate loading for 22 al. (8) 2002 days during the maintenance period. $5 \mathrm{gr}$ creatine monohydrate- 1 gr glucose polymer and 6 gr glucose polymer). Bicycle ergometry: Swimming bench total work efficiency test: $2 \times 30 \mathrm{sec}$ maximal effort sprint with 10 minutes of rest inbetween

Single blind. 10 When compared with the placebo group male $\quad(2,0 \%)$, total work performance was and 10 female statistically significantly higher in the creatine competitor young group $(7,5 \%)$. swimmers (16 years of age),

\begin{tabular}{crl}
\hline & & Randomized, double blind, placebo \\
& controlled \\
Grindstaff et & Daily 21 gr. creatine monohydrate and 4, \\
al.(12) $\quad 1997$ & $\begin{array}{l}\text { gr maltodextrin and daily } 25 \mathrm{gr} \\
\text { maltodextrin for 9 days. } \\
\text { Swimming bench ergometry: } 3 \times 20 \mathrm{sec} \\
\text { upper extremity isokinetic arm ergometr } \\
\text { test (maximal effort sprint) with } 60 \text { sec of } \\
\text { rest between sprints }\end{array}$ \\
\hline
\end{tabular}

Azizi (2) 20115 gr $\times 4$ dose/day $\times 6$ days
Greater change was found in work

18 junior (11 femaleperformance of creatine group when and 9 male) compared with placebo group and a American local and significant recovery $(7,8 \%)$ was found in the national amateur creatine group only during sprint 1 . No swimmers. difference in peak strength between trials and groups. No significant difference was found in the second sprint $(5.3 \%)$ and third sprint $(0.5 \%)$. Total swimming time was found to decrease in the creatine group.

20 female The effects of short term creatine competitor supplementation and anaerobic performance swimmers between and sprint swimming time were assessed and the ages of 17-26 statistically significant increases were found in vertical jump, bench press, sprint run and swimming speed.
Short-term creatine supplementation (5 days) $(20 \mathrm{~g} /$ day $\times 5$ days). 2 × 100 meter

Juhász et al., 2009 maximum paletted swimming test

Significant increases were found in dynamic

Young elite strength and anaerobic strength test results of paletted swimming the lower extremity. It was found to increase athletes performance in consecutive maximum maximal swimming.

$\begin{aligned} & \text { 30-day-long procedure, double-blind } \\ & \text { design. }\end{aligned}$
$\begin{gathered}16 \text { male and female } \\ \text { competitive }\end{gathered}$

Both forms (daily 20 gr) were applied for 6 swimmers were It was shown that creatine and

Mero et al. 2004 days for creatine supplementation and randomly grouped supplementation group loadings positively

(20) placebo. Each treatment included placebo as placebo and influenced consecutive maximal swimming and creatine supplementation in 6 days. Insodium bicarbonateperformance and increased performance in the morning of day 7 , sodium bicarbonate + creatine swimming. loading was made on placebo 2 hours combination. before 2 x $100 \mathrm{~m}$ maximal free style 
swimming training with 10 minutes of

passive rest $(0,3 \mathrm{~g} / \mathrm{kg}$ body weight).

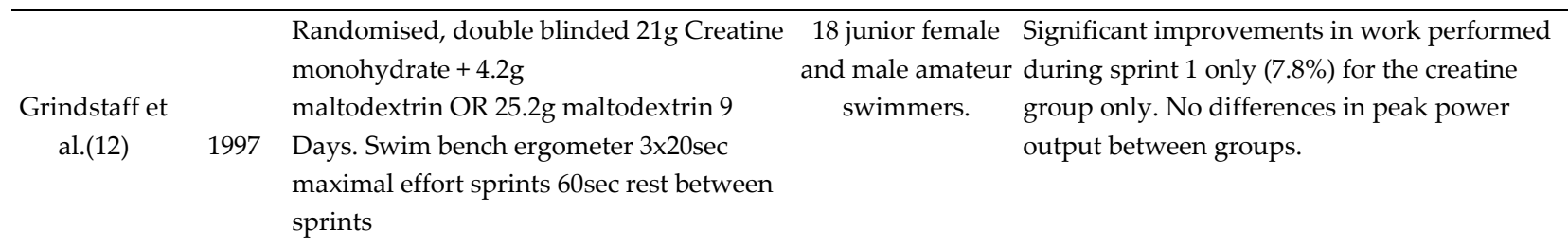

According to Burke, creatine have no effect on strength and peak performance. The other studies showed that creatine use have positive effects on strength.

\section{CONCLUSION AND EVALUATION}

The differences between acute and chronic use of creatine significant performance improvement in sprint -interval- training of swimmers. In the sport of swimming, positive effect of creatine is expected in sprint disciplines before anything else. Strength increase occurs with the increase in muscle mass. 1-2 $\mathrm{kg}$ weight increase occurs in muscles with water retention. This is not tragic in swimming sport; however, it may be tragic in middle and long distance athletes. In swimming sport, a great muscle mass increase is not absolutely useful because the resistance of water increases. Anabolic doping allows higher training content. Better resting ability is recommended for better performance rather than greater muscle mass. Anabolic substances also partly cause aggression. Creatine intake causes better resting ability in intense training periods.

As a conclusion creatine supplement intake in controlled studies in swimmers can present with both plasma concentration increase and with the increase of total creatine amount in muscles and this increase can be reflected positively in performance. It can contribute to aerobic and anaerobic endurance of swimmers' upper and lower extremities, sprint run and sprint swim speed, maximal strength and strength continuation and recovery speed between repetitions and after training. It can be said that findings support that creatine supplementation is not beneficial during single sprint efforts, creatine supplementation is beneficial for improving strength and performance during repeated bouts of high intensity exercise.

\section{REFERENCES}

1. Alpullu A. Uluslararası Basketbol Organizasyonlarının Spor Turizmine Katkılarının Değerlendirilmesi (Doctoral
Dissertation). İstanbul: Marmara University Instituteof Sports Sciences,2011.

2. Anomasiri W. Low Dose Creatine Suplementation Enhances Sprint Phase of 400 Meters Swimming Performance, J.Med. Assoc. Thai; 2004 Vol. 87, Suppl.2, s.228-232

3. Azizi M. The effect of a short-term creatine supplementation on some of the anaerobic performance and sprint swimming records of female competitive swimmers. Procedia-Social and Behavioral Sciences, 2011;15,1626-1629.doi:10.1016/ j.sbspro.2011.03.342.

4. Benzi G, \& Ceci A. Creatine as nutritional supplementation and medicinal product. J Sports Med Phys Fitness. 2001; 41(1):1-10.

5. Burke I, Pyne D, Telford RD. Effect of oral creatine supplementation on single effort sprint performance in elite swimmers. Int J Sport Nutr, 1996; 6, 222-233.

6. Carl DL, Alperin N, Kochendorfer K, Stieger J, Andres F, \& Broadley D. Effect of oral creatine and caffeine on muscle phosphocreatine resynthesis in competitive swimmers. Medicine and Science in Sports and Exercise, 1999; 31(5), Supplement, abstract, 1283.

7. Cecil KM, Salomons GS, Ball WS, Jr, Wong B, Chuck G, Verhoeven NM, Jakobs C \& DeGrauw TJ. Irreversible brain creatine deficiency with elevated serum and urine creatine: a creatine transporter defect? Ann Neurol. 2001; 49 (3): 401-4.

8. Peyrebrune MC, Nevill ME, Donaldson FJ, Cosford DJ. The effects of oral creatine supplementation on performance in single and repeated sprint swimming. Journal of Sport Sciences, 1998; 16, 271-279.

9. Dawson B, Vladich T, Blanksby BA. Effects of 4 Weeks of Creatine Supplementation in Junior Swimmers on Freestyle Sprint and Swim Bench Performance, The Journal of Strength and Conditioning Research: 2002; 16 (4) 4, 485-490.

10. Derave W, Eijnde BO, Verbessem P, Ramaekers M, Leemputte MV, Richter EA, Hespel P. Combined creatine and protein supplementation in conjunction with resistance training promotes muscle GLUT-4 content and glucose tolerance in humans., J Appl Physiol 2003; 94(5):1910-6. DOI: 10.1152/ japplphysiol.00977.2002

11. Dorrell HF, Gee TI, Middleton G An Update on Effects of Creatine Supplementation on Performance: A Review. Sports Nutr Ther 2016; 1: 107. doi: 10.4172/2473-6449.1000107

12. Greenwood M, Greenwood L, Kreider R, Stahura K. Creatine supplementation does not increase perceptions of fatigue or adversely affect health status during three a day training. J Athletic Train. 2002;37: 82. 
13. Grindstaff PD, Kreider R, Bishop R, Wilson M, Wood L, Alexander C, Almada A. Effects of creatine supplementation on repetitive sprint performance and body composition in competitive swimmers. Int J Sport Nutr, 1997; 7, 330-346.

14. Havenetidis K, Cooke C, King R, Denison T. Repeated creatine supplementation and swimming performance. Abstracts of the 1stAnnual Congress of the European College of Sport Science, 1996; 566-567.

15. Jacobs KA, Leenders NY, Sherman WM, Nelson TE, Lamb DR, \& Miller EC. 1998 Creatine (Cr) supplementation and swimming. Medicine and Science in Sports and Exercise, 1998; 30(5), Supplement abstract 1506

16. Juhász I, Györe I, Csende Z, Rácz L, Tihanyi J. Creatine supplementation improves the anaerobic performance of elite junior fin swimmers, Acta Physiol Hung, 2009; 96(3):32536.doi: 10.1556/APhysiol.96. 2009.3.6.

17. Kaemmerer WF, Rodrigues CM, Steer C, Low WC. Creatinesupplemented diet extends Purkinje cell survival in spinocerebellar ataxia type 1 transgenic mice but does not prevent the ataxic phenotype, Neuroscience, 2001; 103(3): 71324.

18. Leemputte MV, Vandenberghe K, Hespel P, Shorting of Muscle Relaxation Time after Creatine Loading, in: J. Appl. Physiol. 1999; 86, 3, 840-844.

19. Leenders N, Sherman WM, Lamb DR, Nelson TE. Creatine supplementation and swimming performance. International Journal of Sport Nutrition, 1999; 9, 252-262

20. Mendes RR, \& Tirapegui J. Effect of creatine supplementation on supramaximal exercise and body composition of university swimmers. Medicine and Science in Sports and Exercise, 2002; 34(5), Supplement abstract 806.

21. Mero AA, Keskinen KL, Malvela MT, Sallinen JM. Combined creatine and sodium bicarbonate supplementation enhances interval swimming. J. Strength Cond. Res. 2004; 18(2): 306310.

22. Mihic S, MacDonald J, McKenzie S, Tarnopolsky MA. Acute creatine loading increases fat-free mass, but does not affect blood pressure, plasma creatinine, or CK activity in men and women. Med Sci Sports Exerc, 2000; 32, 291-296

23. Mujika I, Chatard J, Lacoste F, Barale, F.Geyssant, A. Creatine supplementation does not improve sprint performance in competitive swimmers. Med Sci Sports and Exercise, 1996; 28, 1435-1441.

24. Peyrebrune MC, Stokes K. Hall, GM, Nevill, ME. Effect of Creatine Supplementation on Training for Competition in Elite Swimmers. Medicine \& Science in Sports \& Exercise. 2005; 37(12):2140-2147.

25. Poortmans J, Francaux M, Adverse effects of creatine supplementation: fact or fiction? Sports Med. 2000; 30 (3): 155170.

26. Selsby JT, Beckett KD, Kern M, Devor ST. Swim Performance Following Creatine Supplementation in Division III Athletes, The Journal of Strength and Conditioning Research: 2003, 17(3), 421-424.

27. Stone MH, Sanborn K, Smith LL, O'Bryant HS, Hoke T, Utter AC, Johnson RL, Boros R, Hruby J, Pierce KC, Stone ME, Garner B. Effects of in-season (5 weeks) creatine and pyruvate supplementation on anaerobic performance and body composition in American football players. Int J Sport Nutr, 1999; 9:146-165.

28. Theodorou AS., Cooke CB. Effect of long-term creatine supplementation on elite swimming performance. Journal of Sport Sciences. 1998; 16: 62.

29. Theodorou AS, Cooke CB, King RF, Hood C, Denison T, Wainwright BG, Havenetidis $K$. The effect of longer-term creatine supplementation on elite swimming performance after an acute creatine loading. Journal of Sport Sciences. 1999; 17(11): 853-859

30. Theodorou AS, Havenetidis K, Zanker CL, O'Hara JP, King RF, Hood C, Paradisis G, Cooke CB. Effects of acute creatine loading with or withoug carbohydrate on repeated bouts of maximal swimming in high-performance swimmers. Journal of Strength and Conditioning Research. 2005; 19: 265-269

31. Thompson CH, Kemp GJ, Sanderson AL, Dixon RM, Styles P, Taylor DJ, Radda GK. Effect of oral creatine on aerobic and anaerobic metabolism in skeletal muscle in swimmers. $\mathrm{Br} \mathrm{J}$ Sports Med, 1996; 30, 222-225.

32. Volek JS, Rawson ES. Scientific basis and practical aspects of creatine supplementation for athletes, Nutrition, 2004; 20(78): 609-614, doi.org/10.1016/ j.nut.2004.04.014

33. Wyss M, and Kaddurah-Daouk R. Creatine and creatinine metabolism. Physiological Reviews. 2000; 80: 1107-1213.

34. Yquel RJ, Arsac LM, Thiaudière E, Canioni P, Manier G. Effect of creatine supplementation on phosphocreatine resynthesis, inorganic phosphate accumulation and $\mathrm{pH}$ during intermittent maximal exercise. J Sports Sci. 2002;20:427-37.

35. https://www.mayoclinic.org/drugs-supplements-creatine/art20347591?pg=2 